\title{
Perancangan Aplikasi Berbasis Android Jadwal Service Sepeda Motor Pada Bengkel Ridho Motor
}

\author{
*Muhammad Ridwan Effendi ${ }^{1)}$, Fenty Tristanti Julfia ${ }^{2)}$, Mohammad Narji ${ }^{3)}$ Dandi Wanara ${ }^{4)}$ \\ ${ }^{1)}$ Program Studi Sistem Informasi, Universitas Mohammad Husni Thamrin \\ ${ }^{233) 4}$ Program Studi Teknik Informatika, Universitas Mohammad Husni Thamrin
}

Correspondence Author: Muhammad Ridwan Effendi, jundi79@gmail.com

DOI: https://doi.org/10.37012/jtik.v7i2.649

\begin{abstract}
Abstrak
Kendaraan bermotor merupakan alat yang digunakan sebagai alat bantu manusia untuk bisa berpindah dari satu tempat ke tempat lain. Salahsatu kendaraan bermotor yang ada pada saat ini adalah motor. Motor sebagai kendaraan bagi masyarakat memerlukan perawatan agar terawat dan tidak mudah rusak. Untuk melakukan perawatan dan pergantian suku cadang, maka memerlukan sarana bengkel. Karena bengkel dapat melakukan perawatan dan pergantian suku cadang yang sudah rusak. Bengkel motor yang ada saat ini ada dua jenis, yaitu bengkel resmi/ATPM dan tidak resmi. Pada bengkel diluar bengkel resmi juga banyak dikunjungi oleh pemilik motor dari berbagai merek. Salahsatu bengkel motor milik perorangan adalah bengkel yang memiliki nama Bengkel Ridho Motor. Untuk mengadministrasi dan merawat data pelanggan, seperti memberitahukan jadwal service, jadwal pergantian suku cadang dan lain-lain. Untuk memudahkan dalam pemberitahuan kepada pelanggan, maka pemilik merasa perlu membuat aplikasi berbasis mobile dari bengkel yang dikelola. Tujuan dari pembuatan aplikasi ini adalah memudahkan pemilik memberitahukan jadwal service dan pergantian suku cadang kepada pelanggan. Perancangan aplikasi berbasis mobile ini menggunakan bahasa pemrograman berbasis android. Penelitian ini menggunakan metode pembangunan aplikasi yaitu metode waterfall. Hasil akhir penelitian ini adalah berupa aplikasi berbasis mobile menggunakan android.
\end{abstract}

Kata kunci : Perancangan Aplikasi Service, Bengkel Sepeda Motor, Android

\begin{abstract}
Motorized vehicles are tools that are used as a tool for humans to be able to move from one place to another. One of the motor vehicles that exist today is a motorcycle. Motorcycles as vehicles for the community require maintenance to be maintained and not easily damaged. To carry out maintenance and replacement of spare parts, it requires workshop facilities. Because the workshop can carry out maintenance and replacement of damaged parts. There are currently two types of motorcycle workshops, namely official/ATPM workshops and informal workshops. In workshops outside the official workshop, there are also many motorcycle owners from various brands visited. One of the privately owned motorcycle workshops is a workshop that has the name Ridho Motor Workshop. To administer and maintain customer data, such as notifying service schedules, spare parts replacement schedules and others. To make it easier to notify customers, the owner feels the need to create a mobile-based application from the managed workshop. The purpose of making this application is to make it easier for owners to notify customers of service schedules and replacement of spare parts. The design of this mobile-based application uses an android-based programming language. This study uses the application development method, namely the waterfall method. The final result of this research is a mobile-based application using Android.
\end{abstract}

Keywords: Service Application Design, Motorcycle Workshop, Android 


\section{PENDAHULUAN}

Data dari BPS (Biro Pusat Statistik) Jakarta pada tahun 2020 mengenai jumlah sepeda motor di DKI Jakarta berjumlah 16.141.380 unit sepeda motor dari berbagai merek dan jenis sepeda motor. Mulai dari sepeda motor matik maupun bukan matik seperti sepeda motor bebek, sepeda motor menggunakan kopling dan sport. Dari data diatas dapat dijelaskan bahwa sepeda motor yang ada di DKI Jakarta memerlukan bengkel atau tempat merawat sepeda motor tersebut. Bengkel yang ada di DKI Jakarta ada dua jenis, yaitu bengkel resmi dari merek motor dan bengkel tidak resmi yang dimiliki oleh perorangan maupun perusahaan selain ATPM sepeda motor.

Bengkel Ridho Motor merupakan bengkel sepeda motor yang telah berdiri sejak tanggal 01 Januari 1996. Awalnya, Bengkel Ridho Servis adalah bengkel umum yang melayani jasa servis seluruh tipe dan merek kendaraan bermotor. Seiring berjalannya waktu, Bengkel Ridho Servis sedikit demi sedikit mulai melakukan penjualan sepeda motor baru dari berbagai macam merek sesuai dengan permintaan konsumen. Dari hasil penjualan ini, Bengkel Ridho Servis mulai mengalami perkembangan bahkan kemajuan yang pesat mengingat besarnya permintaan konsumen terhadap sepeda motor dari berbagai merek pada waktu itu. Melihat besarnya penjualan yang dapat dilakukan membuat salah satu perusahaan sepeda motor ternama yang ada di Indonesia, yaitu Yamaha merasa tertarik untuk menjadikan Bengkel Ridho Servis menjadi salah satu bengkel resminya. Maka dari itu, pada tahun 2004 Bengkel Ridho Servis resmi menjadi bengkel resmi Yamaha yang terletak di Jl. Bacang Raya, Kec. Bekasi Selatan, Kota Bekasi, Jawa Barat dan terus mengalami perkembangan hingga saat ini dan telah berhasil membuka tiga cabang baru, yaitu di Jl. Konsen/Kranggan, Kec. Jatiasih, Kota Bekasi, Jawa Barat.

Pemberitahuan penjadwalan service sepeda motor adalah bentuk pelayanan dari bengkel motor Ridho kepada pelanggan. Karena dengan adanya layanan pemberitahuan penjadwalan tersebut maka pelanggan diharapkan tidak lupa dan terlewat apabila sudah waktunya melakukan service rutin sepeda motornya. Perbaikan atau service dan pergantian suku cadang kendaraan motor sangat penting bagi pemilik. Perbaikan, perawatan dan pergantian suku cadang akan menjaga kendaraan motor bisa awet dan dalam kondisi yang baik. Terkadang konsumen lupa akan waktu untuk melakukan pemeriksaan, pergantian oli, suku cadang dari motornya. Untuk mengatasi masalah keterlambatan dalam perawatan motor maka dibutuhkan aplikasi berbasis mobile atau android untuk mengingatkan pelanggan dari bengkel Ridho. 
Dalam studi ini dirancang aplikasi untuk aktivitas penjadwalan service motor berbasis android. Alasan pengambilan studi ini dikarenakan aktivitas manajemen material di galangan kapal masih menggunakan cara manual dibantu komputer yang membutuhkan waktu dalam penyampaian informasi dan sering terjadi kesalahan informasi antar pihak yang terkait.

\section{METODE}

Menurut Rosa dan Shalahuddin menjelaskan bahwa model Waterfall adalah model SDLC yang paling sederhana, model ini hanya cocok untuk pengembangan perangkat lunak dengan spesifikasi yang tidak berubah-ubah. Penulis menggunakan model pengembangan sistem waterfall. Model waterfall sering juga disebut model sekuensial linier (sequential linear) atau alur hidup klasik (classic life cycle). Model air terjun (waterfall) menyediakan pendekatan alur hidup perangkat lunak secara sekuensial atau terurut dimulai dari analisis, desain, pengkodean, pengujian, dan tahap pendukung (support). Menurut Pressman (2012), perancangan adalah langkah pertama dalam fase pengembangan rekayasa produk atau sistem. Perancangan itu adalah proses penerapan berbagai teknik dan prinsip yang bertujuan untuk mendefinisikan sebuah peralatan, satu proses atau satu sistem secara detail yang membolehkan dilakukan realisasi fisik. Pengertian Aplikasi menurut (Jogiyanto, 2010) adalah penggunaan dalam suatu komputer, instruksi (instruction) atau pernyataan (statement) yang disusun sedemikian rupa sehingga komputer dapat memproses input menjadi output. Pertama kali Android Studio diumumkan di Google I/O Conference pada tahun 2013 dan dirilis ke publik pada tahun 2014. Sebelum lahirnya Android Studio, aplikasi pada Android dikembangkan dengann Eclipse IDE yaitu IDE Java. Setelah adanya android studio yang open source dapat memudahkan bagi Anda yang ingin membuat aplikasi dengan Android Studio. Berikut ini adalah beberapa fitur Android Studio:

a) Environment yang mempermudah Anda untuk mengembangkan aplikasi untuk Android

b) Support dalam mengembangkan aplikasi Android TV dan Android Wear

c) Template untuk menentukan design dan komponen Android

d) Editor layout dengan interface drag-and-drop

e) Refactoring dan perbaikan cepat khusus Android

f) Dukungan build berbasis Gradle

g) Integrasi ProGuard

h) Emulator yang cepat dan berbagai fitur didalamnya 
i) Dapat terintegrasi dengan Google Cloud Messaging dan App Engine

Dukungan program basic $C++$ dan $N D K$

Menurut Wibawanto (2017:20) "Flowchart adalah suatu bagan dengan simbolsimbol tertentu yang menggambarkan urutan proses secara mendetail dan hubungan antara suatu proses (intruksi) dengan proses lainnya dalam suatu program". Diagram alur dapat menunjukan secara jelas, arus pengendalian suatu algoritma yakni bagaimana melaksanakan suatu rangkaian kegiatan secara logis dan sistematis

Unified Modelling Language (UML) adalah bahasa pemodelan untuk sistem atau perangkat lunak yang berparadigma berorientasi objek. Konsep dasar UML terdiri dari structural classification, dynamic behavior, dan model management. UML mendefinisikan diagram-diagram sebagai Use case diagram, Class diagram, State chart diagram, Activity diagram, Sequence diagram, Collaboration diagram, Component diagram, dan Deployment diagram.

\section{HASIL DAN PEMBAHASAN}

Berikut adalah hasil perancagan dengan UML (Unified Modeling Language) meliputi diagram Use Case dan diagram aktivitas.

Diagram Usecase Login

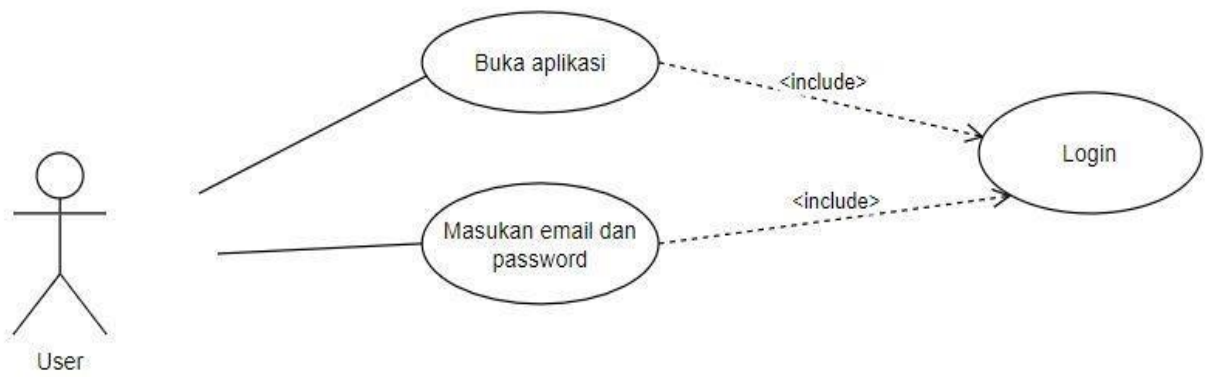

Gambar 1 Usecase Login 


\section{Tabel 1 Deskripsi tabel Usercase Login}

Usecase name

\section{Login}

\begin{tabular}{|l|l|}
\hline Reqruitment & User melakukan login \\
\hline Goal & User berhasil login \\
\hline Pre-Condition & $\begin{array}{l}\text { User memasukkan nama pengguna dan } \\
\text { kata sandi }\end{array}$ \\
\hline Post-Conditiont & User masuk ke menu utama \\
\hline Failed and Conditions & User tidak dapat melakukan login \\
\hline Actors & Servis counter \\
\hline Main Flow & 1. User memasukkan nama pengguna \\
& 2. User memasukkan kata sandi \\
\hline
\end{tabular}

Diagram Usecase Registrasi Servis Motor

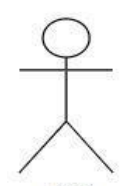

User

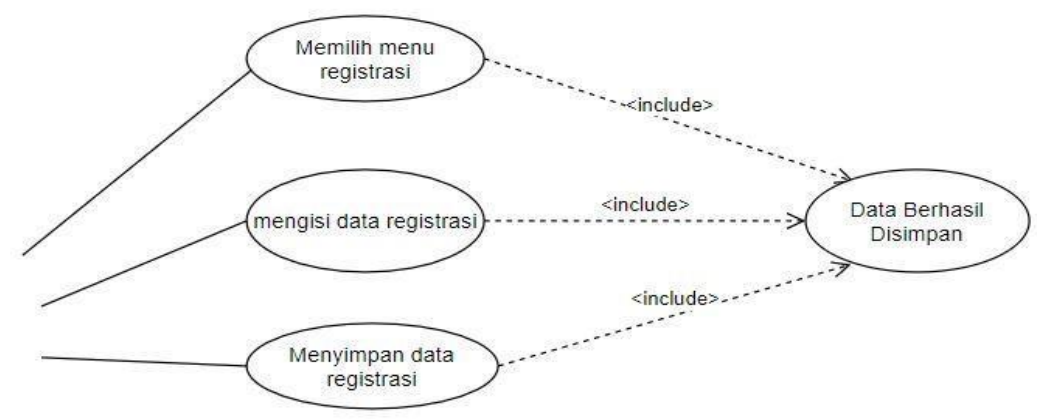

Gambar 2 Usecase registrasi

Tabel 2 Deskripsi tabel Usecase Registrasi

Usecase name

Usecase registrasi

\begin{tabular}{|l|}
\hline Reqruitment \\
\hline Goal \\
\hline Pre-Conditions \\
\hline Post-Conditions \\
\hline Failed and Conditions \\
\hline
\end{tabular}

Actors
Melakukan pendaftaran

User berhasil melukan pendaftaran

User mengisi data registrasi

User menyimpan data registrasi

User gagal melakukan registrasi

Servis counter 

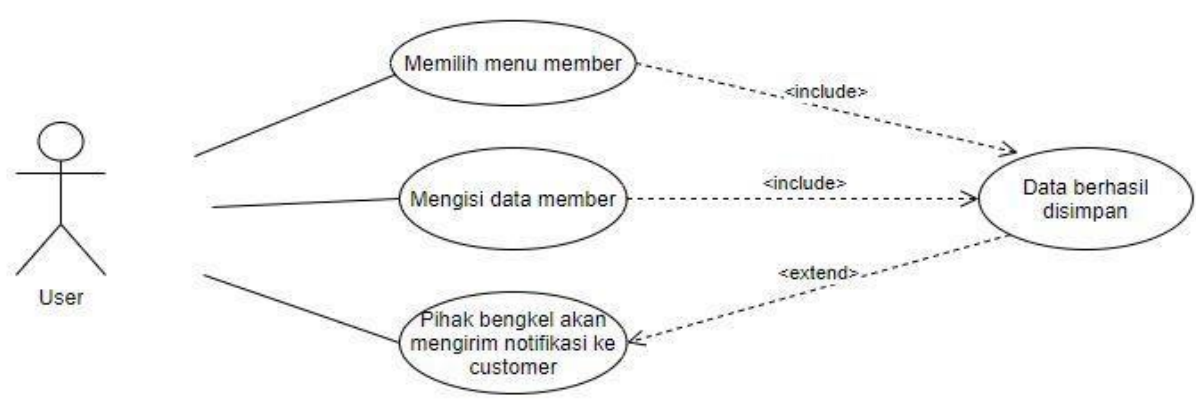

Gambar 3 Usecase Member

Tabel 3 Deskripsi Usecase Member

\begin{tabular}{|l|l|} 
Usecase name & Usecase member \\
\hline Reqruitment & Mengisi data member \\
\hline Goal & User berhasil menyimpan data member \\
\hline Pre-Conditions & User mengisi data member \\
\hline Post-Conditions & User menyimpan data member \\
\hline Failed and Conditions & $\begin{array}{l}\text { User tidak dapat menyimpan data } \\
\text { member }\end{array}$ \\
\hline Actors & Servis counter \\
\hline Main Flow/ Basic Path & $\begin{array}{l}\text { User memilih menu member } \\
\text { User mengisi data member } \\
\text { User menyimpan data data member }\end{array}$ \\
\hline
\end{tabular}

\section{Diagram Usecase Data Member Servis Motor}
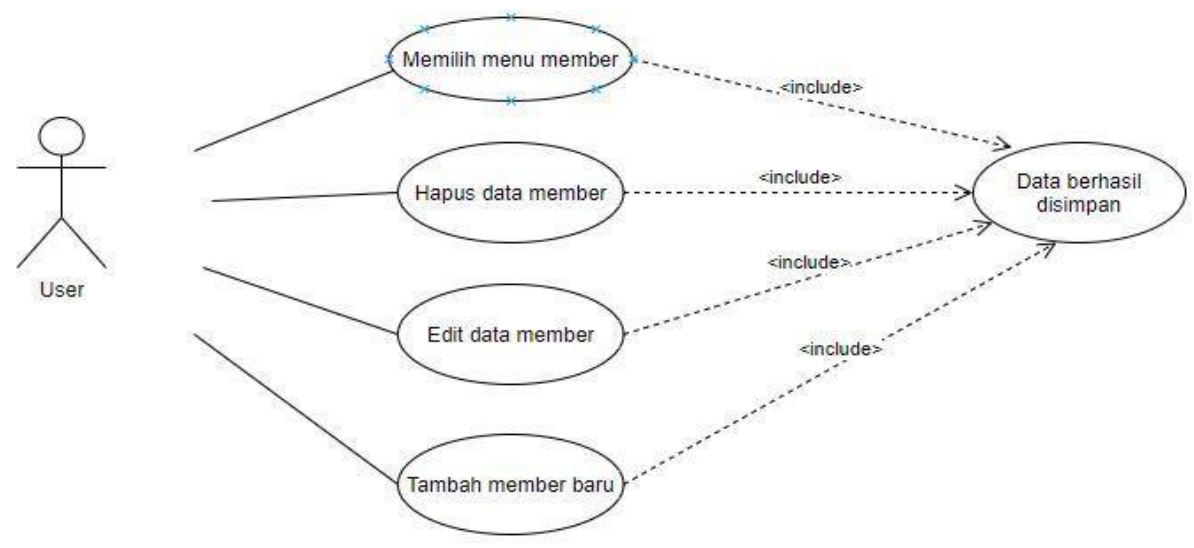

Gambar 4 Usecase Data Member 
Tabel 4 Deskripsi Usecase Data Member

\begin{tabular}{|l|l|} 
Usecase name & Usecase Data Member Servis Motor \\
\hline Reqruitment & Mengupdate data member \\
\hline Goal & User berhasil menyimpan data member \\
\hline Pre-Conditions & User mengupdate \\
\hline Post-Conditions & User menyimpan data member \\
\hline Failed and Conditions & $\begin{array}{l}\text { User tidak dapat menyimpan data } \\
\text { member }\end{array}$ \\
\hline Actors & Servis counter \\
\hline Main Flow/ Basic Path & $\begin{array}{l}\text { User memilih menu member } \\
\text { User mengupdate data member } \\
\text { User menyimpan data data member }\end{array}$ \\
\hline
\end{tabular}

Diagram Usecase Service
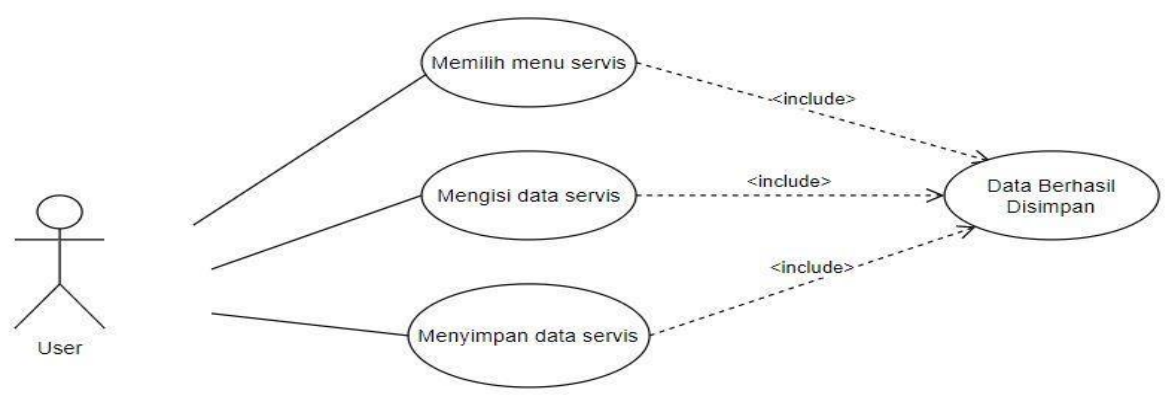

Gambar 5 Usecase Service

Tabel 5 Deskripsi Usecase Servis

\begin{tabular}{l|l} 
Usecase name & Usecase servis \\
\hline Reqruitment & Melakukan servis \\
\hline Goal & User berhasil menyimpan data servis \\
\hline Pre-Conditions & User mengisi data servis \\
\hline Post-Conditions & User menyimpan data servis \\
\hline Failed and Conditions & User gagal menyimpan data servis \\
\hline Actors & Servis Counter \\
\hline
\end{tabular}



Volume 7 No 2; September 2021

\section{Diagram Activity Login}

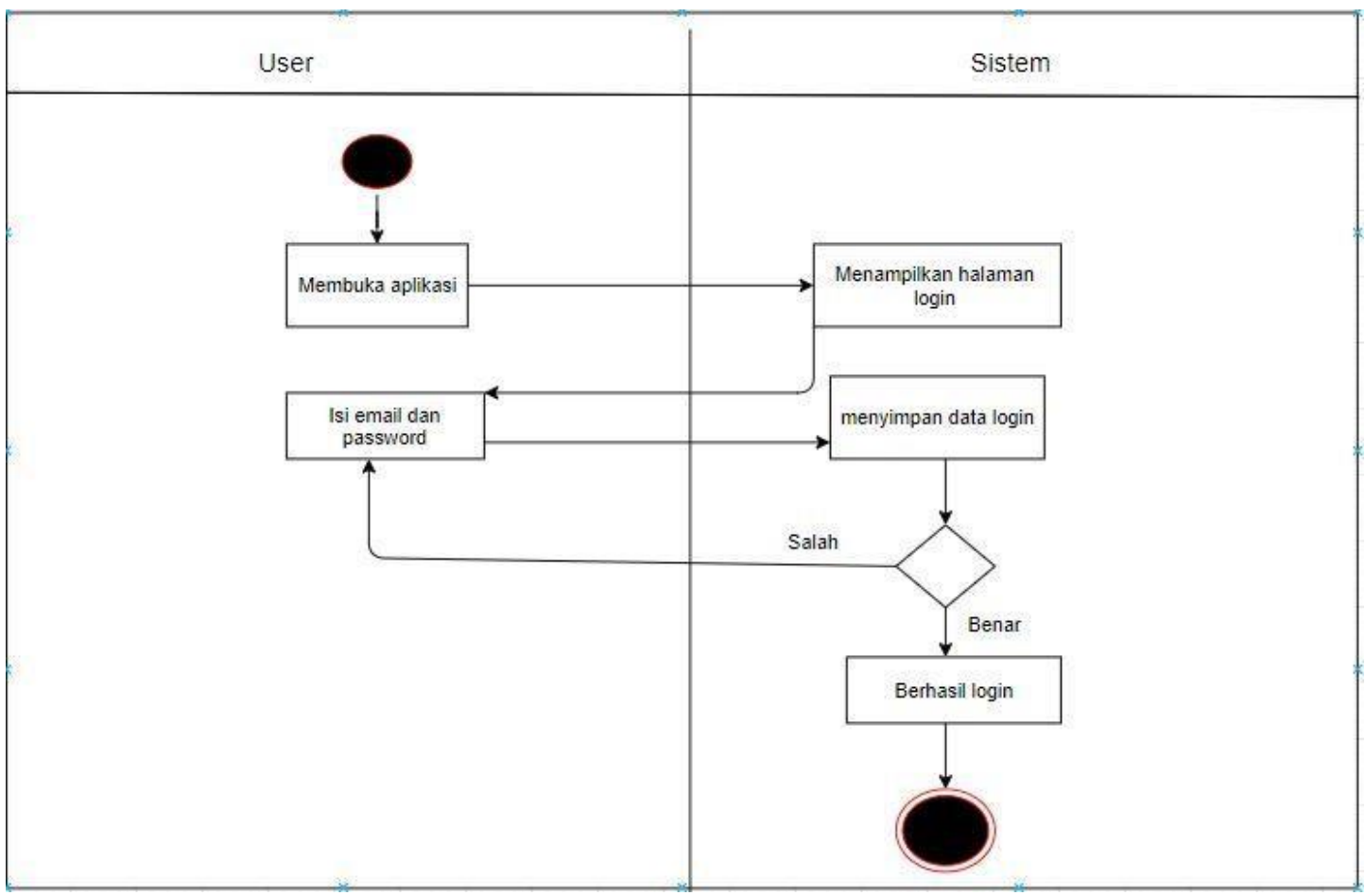

Gambar 6 Activity login

\section{Diagram Activity Registrasi Servis Motor}

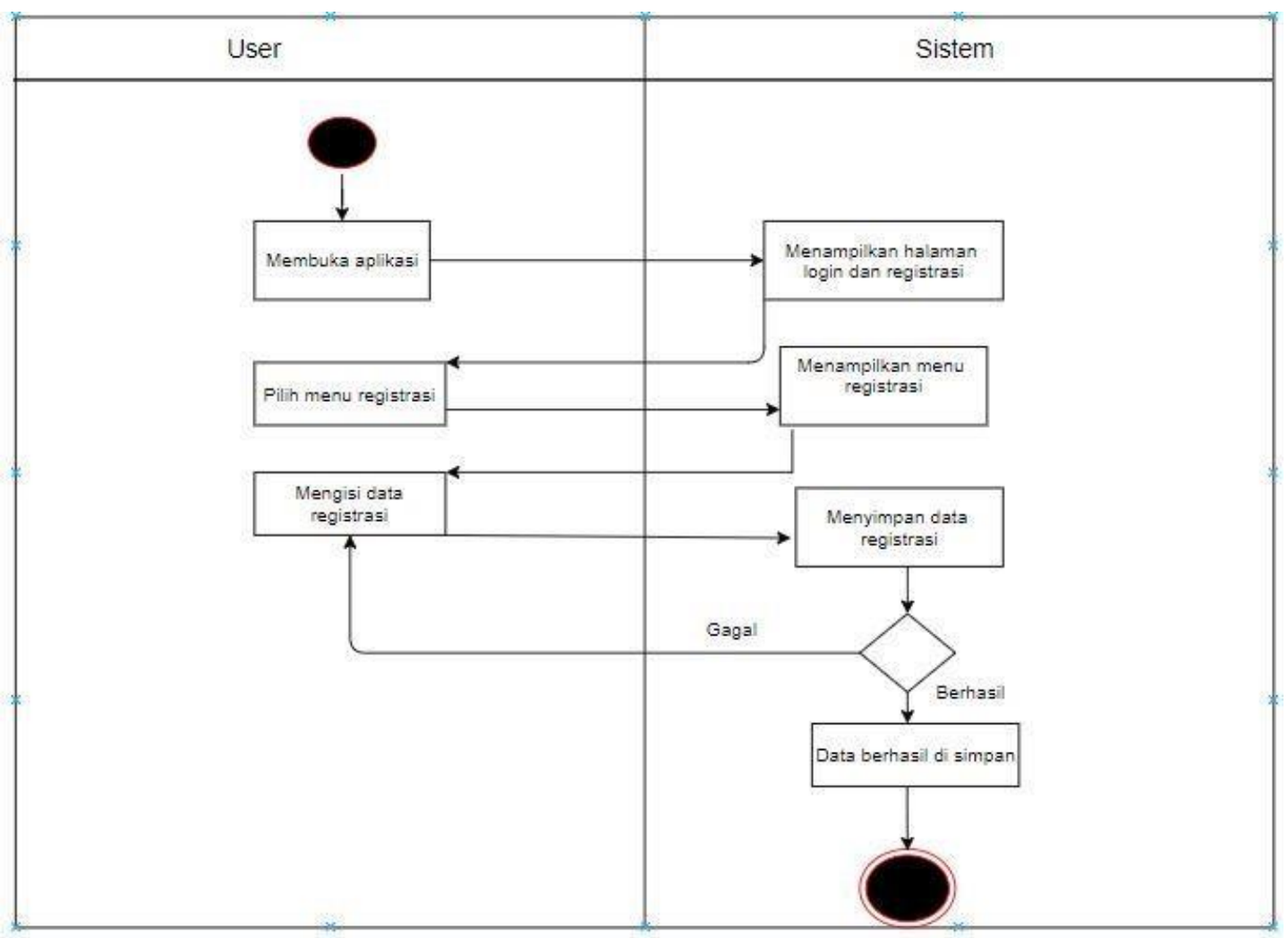

Gambar 7 Activity Registrasi 


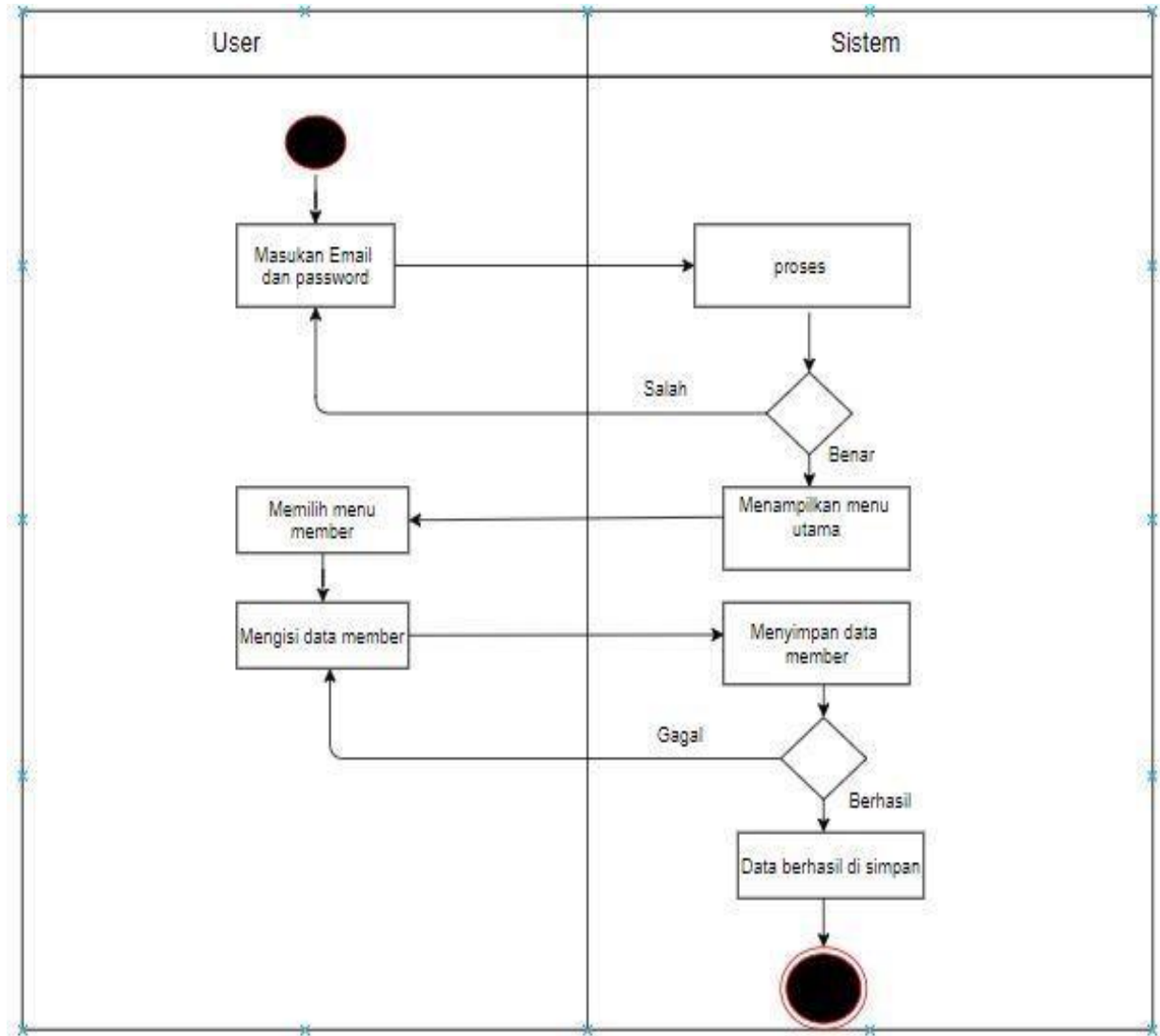

Gambar 8 Activity Member

Diagram Activity Service motor

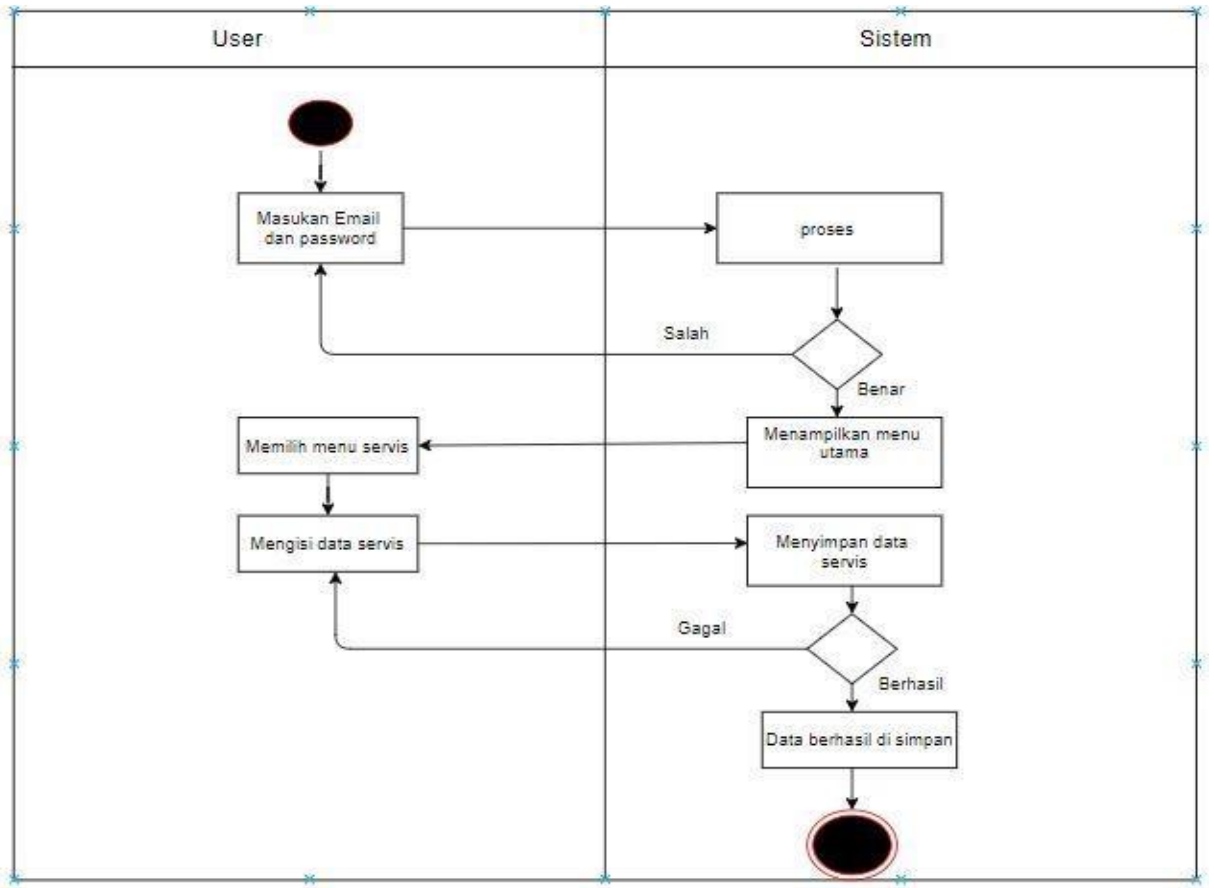

Gambar 9 Activity Service 
Gambar 10 Tampilan Awal Aplikasi

Tampilan Form Login

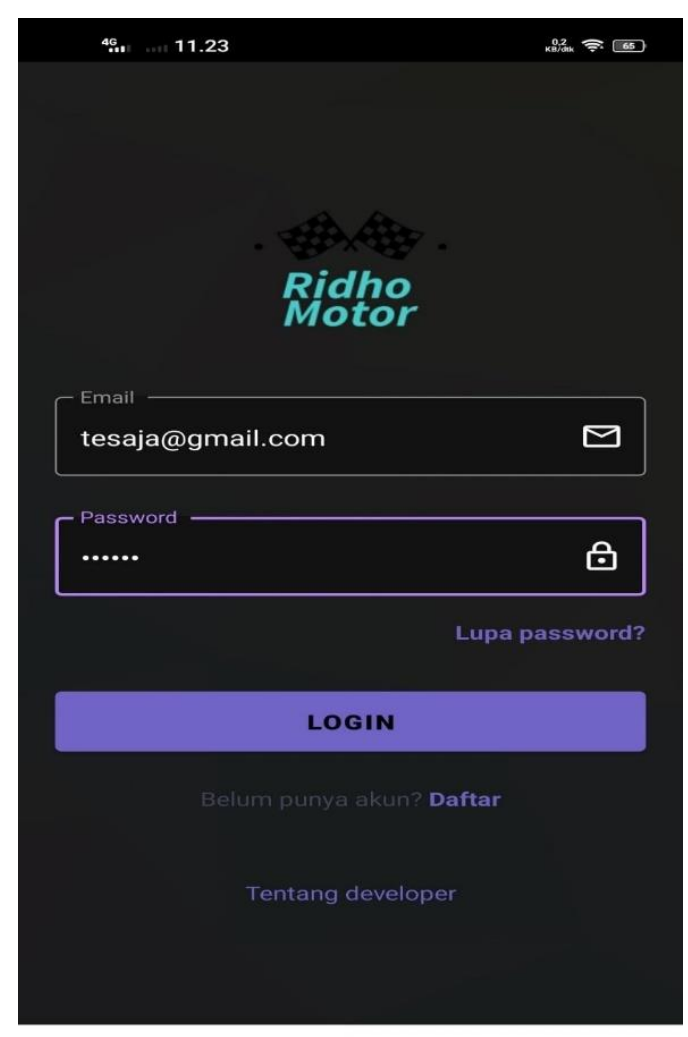

Gambar 11. Tampilan Form login 
Volume 7 No 2; September 2021

Tampilan Form Registrasi

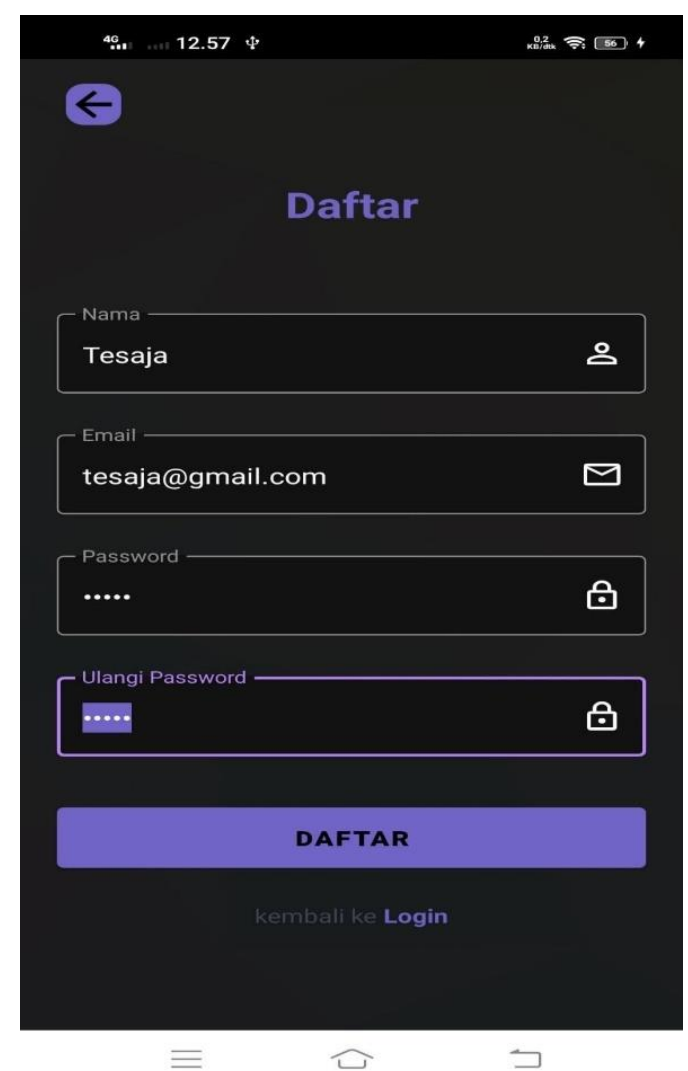

Gambar 12 Form Registrasi

Tampilan Form Member

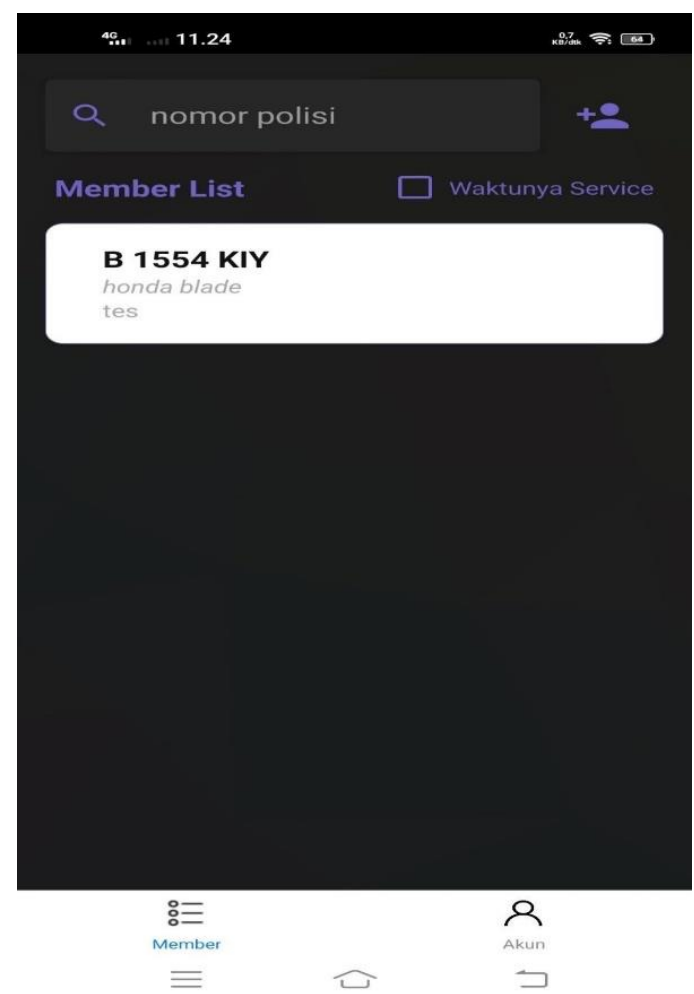

Gambar 13 Tampilan Form Member 


\section{Tampilan Form Tambah Member Baru}

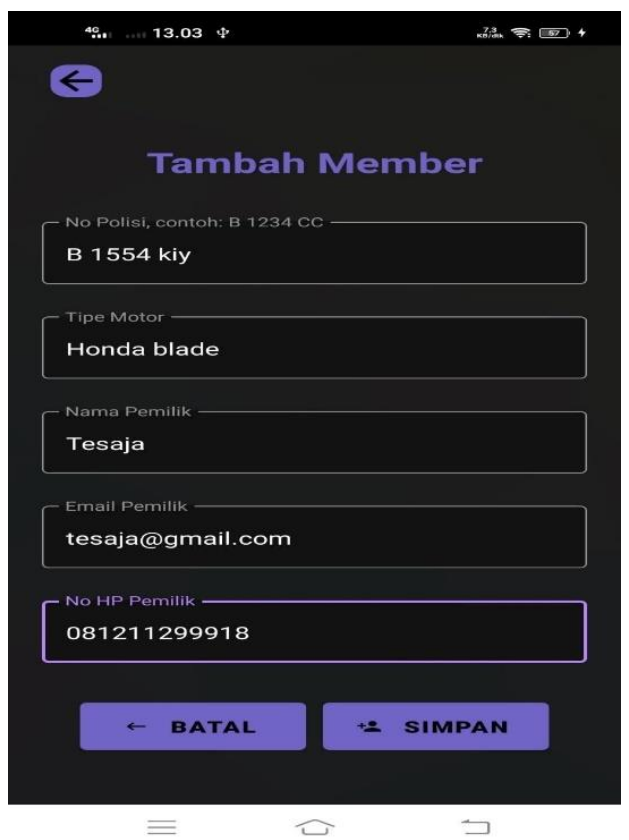

Gambar 14 Tampilan Form Tambah Member Baru

Tampilan Form Edit Member

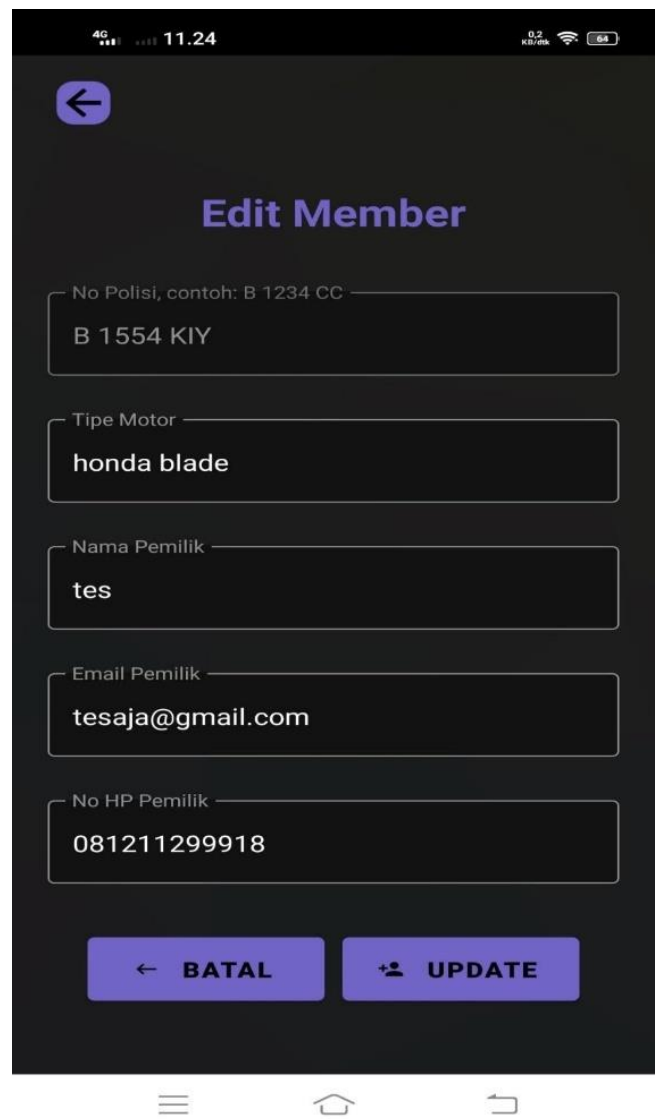

Gambar 15 Tampilan Form Edit Member 


\section{Form Servis}

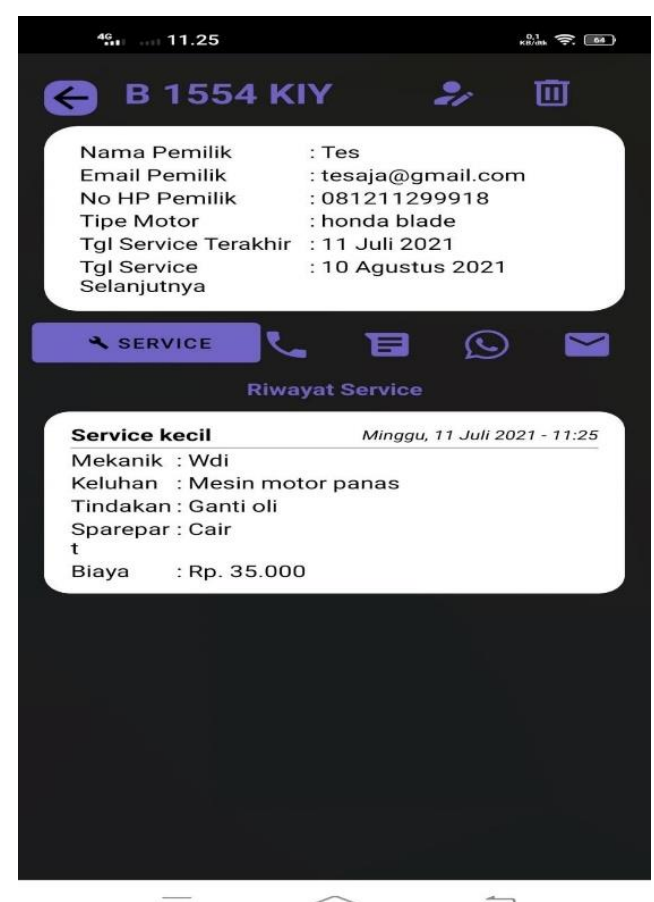

Gambar 16. Form Servis

Form Tambah Servis Baru

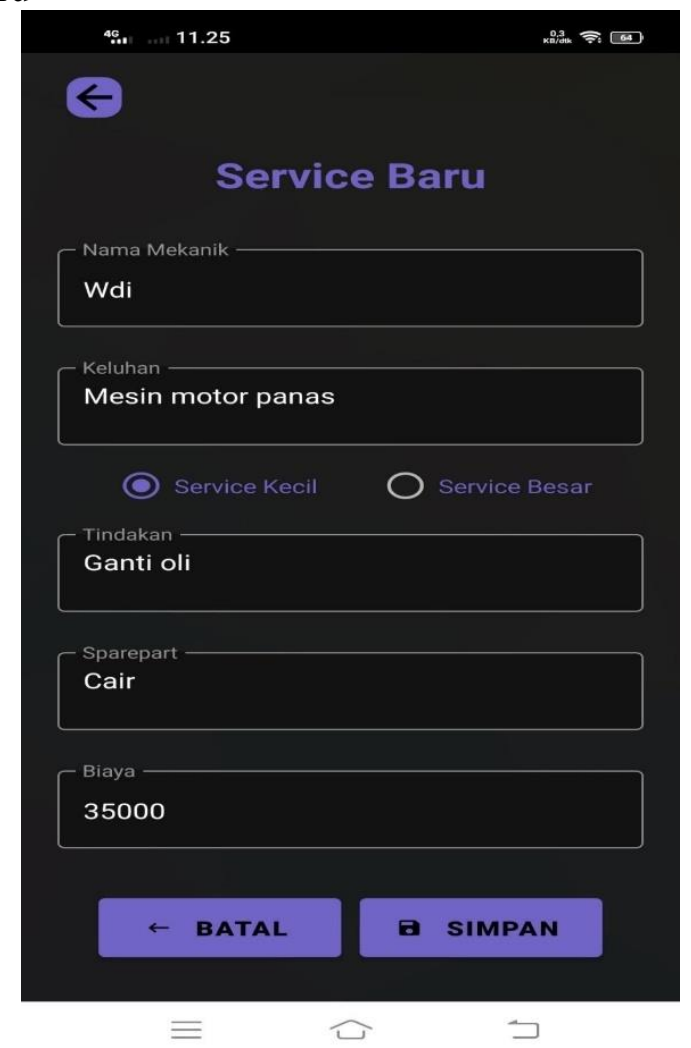

Gambar 17 Form Tambah Service Baru 
Form Notifikasi

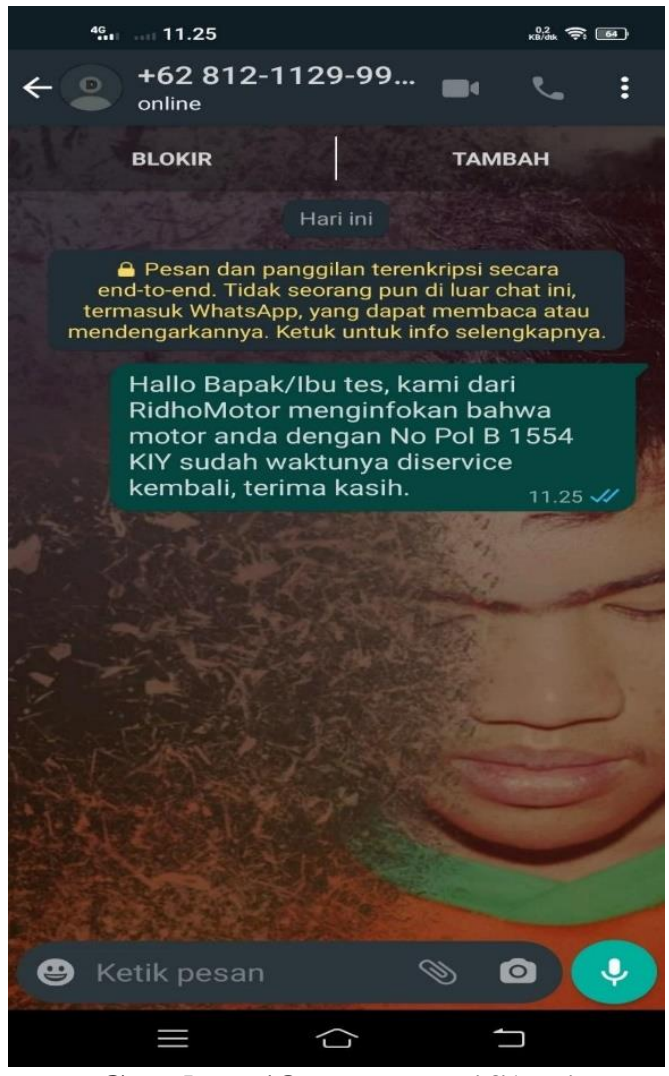

Gambar 18 Form Notifikasi

\section{SIMPULAN}

Dari hasil penelitian " Perancangan Aplikasi Berbasis Android Jadwal Service Sepeda Motor Pada Bengkel Ridho Motor" ini, disimpulkan sebagai berikut :

1. Sistem yang sudah berjalan di bengkel ridho ini tidak efektif dan efisien bagi pihak bengkel untuk menggelola servis motor

2. Dengan dibuatnya suatu aplikasi ini diharapkan dapat menjadi solusi atas masalahmasalah yang sering terjadi seperti kurang mantapnya pengecekan motor serta informasi yang terbatas mengenai riwarat kondisi motor customer

\section{DAFTAR PUSTAKA}

Agustino, R., Widodo, Y. B., Wiyatno, A., \& Saputro, M. I. (2020). Sistem Informasi Penelitian dan Pengabdian Masyarakat di Universitas Mohammad Husni Thamrin. Jurnal Jaring SainTek, 2(1), 1-12.

Jogiyanto H.M , 1990Analisis dan Desain Sistem Informasi. Yogyakarta: Andi Offset.

Kadir, Abdul. (2017). Pemrograman Arduino dan Processing. Jakarta. Elex Media Komputindo. 
Kusrini M.Kom, 2007. Strategi Perencanaan dan Pengelolaan Basis Data.: Andi Offset.

Pressman, Roger S. 2010. Software Engineering : A Practitioner's Approach, Seventh Edition. Mc Graw Hill Higher Education.

$\begin{array}{lllll}\text { Shalahuddin, } & \text { Rosa } & 2014 . & \text { Rekayasa } & \text { Perangkat }\end{array}$ Lunak Berorientasi Objek.

Sopian, A., Agustino, R., \& Wiyatno, A. (2020). Perancangan Aplikasi Surat Menggunakan Framework Codeigniter Dan Bootstrap Pada LPPM Universitas Mohammad Husni Thamrin. Jurnal Teknologi Informatika dan Komputer, 6(2), 47-62.

Wibawanto, W., 2017. Desain dan Pemrograman Multimedia Pembelajaran Interaktif. Jember: Cerdas Ulet Kreatif 